\title{
Karakteristik Sistem Akuifer pada Formasi Endapan Permukaan di Daerah Sei Mati Kota Medan Berdasarkan Metode Geolistrik 2D
}

\author{
(Characteristics of Aquifer Systems in Surface Deposit Formation in Sei Mati Area, \\ Medan City Based on 2D Geoelectrics Methods) \\ Deden Zaenudin Mutaqin ${ }^{*}$, Undang Mardiana, Muhammad Kurniawan Alfadli, \\ Febriwan Mohammad, Yuyun Yuniardi, Andi Agus Nur \\ Jurusan Teknik Geologi, Fakultas Teknik Geologi, Universitas Padjadjaran, Sumedang \\ Jl. Raya Bandung Sumedang No.Km. 21 Sumedang 45363 \\ ${ }^{*}$ Penulis Korespondensi E-mail: deden13005@mail.unpad.ac.id
}

\begin{abstract}
Abstrak
Daerah Sei mati memiliki potensi sumber daya air yang baik, dikarenakan daerah yang termasuk Cekungan Air tanah Medan. Penelitian ini bertujuan untuk mengetahui potensi airtanah dengan menggunakan metode geolistrik 2D dengan konfigurasi wenner-schulumberger. Hasil penelitian menunjukan terdapat 2 lapisan akuifer yaitu akuifer dangkal dan dalam. Lapisan akifer dangkal berada pada kedalaman berkisar antara 0 - 50 meter, membentuk pola channel-channel yang menunjukan endapan fluvial dengan nilai tahanan jenis antara $5 \Omega . m$ - $10 \Omega . m$, dengan litologi pasir lempungan, namun dibeberapa tempat dijumpai channel lempung yang bersifat akuiklud (tidak dapat menyimpan air). Lapisan akuifer dalam muncul pada kedalaman 50 meter hingga 100 meter dengan litologi pasir.
\end{abstract}

Kata Kunci: akuifer, geolistrik, seimati.

\begin{abstract}
The Sei Mati area has good potential for water resources, due to areas that include the Medan Groundwater Basin. This study aims to determine the potential of groundwater using $2 D$ geoelectric methods with Wenner Schlumberger configuration. The results showed that there were 2 layers of aquifers, namely shallow and deep aquifers. The shallow aquifer layer is at a depth of between 0 - 50 meters, forming a channel pattern that shows fluvial deposits with a resistivity value of between 5 S.m - 10 S.m with clay sand lithology, but in some places encountered clay channels that are aquicludThe deep aquifer layer is at a depth of 50 meters to 100 meters, with sand lithology.
\end{abstract}

Keywords: aquifer, geoelectric, sei mati.

\section{PENDAHULUAN}

Sumber daya air di lingkungan tropis biasanya dianggap cukup jumlahnya karena curah hujannya yang besar dan mudah untuk berpikir bahwa masalah air jarang terjadi di Sei mati. Namun demikian, distribusi curah hujan tropis sangat heterogen baik dalam ruang dan waktu yang memicu konflik penggunaan air antara konsumen air seperti petani atau perusahaan industri. Konflik-konflik ini berasal dari rendahnya pengetahuan tentang siklus air oleh para pengguna [1].

Iklim tropis dicirikan oleh musim hujan musiman dengan curah hujan tinggi selama beberapa bulan dan musim kemarau dengan hampir tidak ada hujan. Pada sudut pandang hidrologi, air permukaan hampir tidak tersedia selama musim kemarau karena alirannya bersifat sementara. Oleh karena itu, iklim bukan satu-satunya yang bertanggung jawab atas distribusi sumber daya air yang tidak merata. Selama musim kemarau atau di lokasi di mana hujan hampir tidak terdistribusi, air tanah merupakan sumber air utama dan kadang-kadang unik. Sumber daya ini bergantung pada iklim melalui pengisian ulang tetapi juga struktur geologi, sifat hidrolik akuifer dan tingkat pengguna. Memang, peningkatan demografi, intensifikasi praktik pertanian beririgasi dan perdagangan perusahaan air minum swasta di daerah-daerah ini meningkatkan tekanan pada sumber daya air [1].

Secara Regional, Daerah Sei mati dan sekitarnya, Kota Medan, Provinsi Sumatera Utara, memiliki potensi sumber daya air yang baik, dikarenakan daerah yang termasuk Cekungan Air tanah Medan [2]. Pendugaan keberadaan air tanah dilakukan dalam dua cara yaitu melalui survei permukaan dan survei bawah permukaan. Survei permukaan yaitu dengan overlay peta geologi, administrasi dan peta topografi, setelah itu dianalisis untuk penentuan tempat pendugaan/survey bawah permukaan. Survey bawah permukaan yaitu dengan memanfaatkan metode geolistrik untuk mengetahui nilai resistivitas. Nilai yang diketahui dapat digunakan untuk menggambarkan kondisi akuifer (lapisan bawah tanah yang mengandung air dan dapat mengalirkan air) bawah permukaan. Kegiatan ini dilaksanakan untuk memberikan informasi pendugaan keberadaan dari airtanah dengan menggunakan metode geolistrik 2D. 


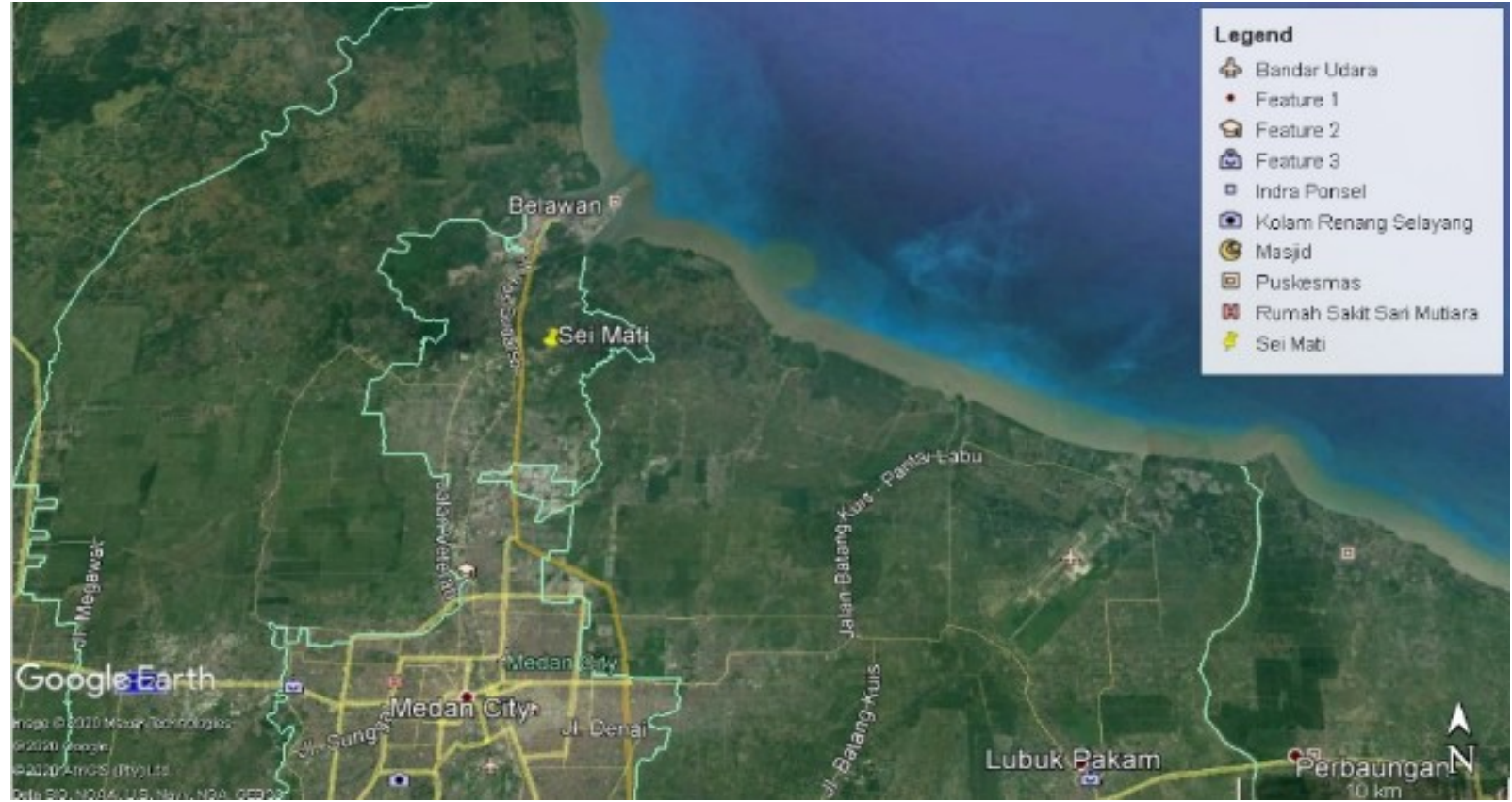

Gambar 1. Peta lokasi daerah penelitian (sumber: google earth)

\section{KEADAAN UMUM}

Pengukuran geolistrik dilaksanakan di kelurahan Seimati Kecamatan Medan Labuhan, Kota Medan. Secara morfologi daerah ini merupakan daerah rawa dan pantai. Daerah ini berasa pada elevasi 15 mdpl kebawah, dengan kemiringan lereng termasuk datar. Secara geologi regiobal, daerah Sei mati termasuk kedalam lembar peta Medan [3] yang tersusun oleh endapan permukaan pantai dan fluvial yang terdiri dari kerikil, pasir, dan lempung yang berumur Quarter.

Secara hidrogeologi regional [2] daerah kajian berdasarkan komposisi batuan dan kelulusannya termasuk ke dalam endapan permukaan yang terdiri dari kerikil, pasir, dan lempung, berkelususan sedang hingga tinggi; dengan akuifer produktivitas tinggi dan penyebaran luas dimana aquifer dengan keterusan sedang sampai tinggi, muka airtanah di atas atau dekat muka tanah dengan debit sumur umumnya lebih dari 101/dtk.

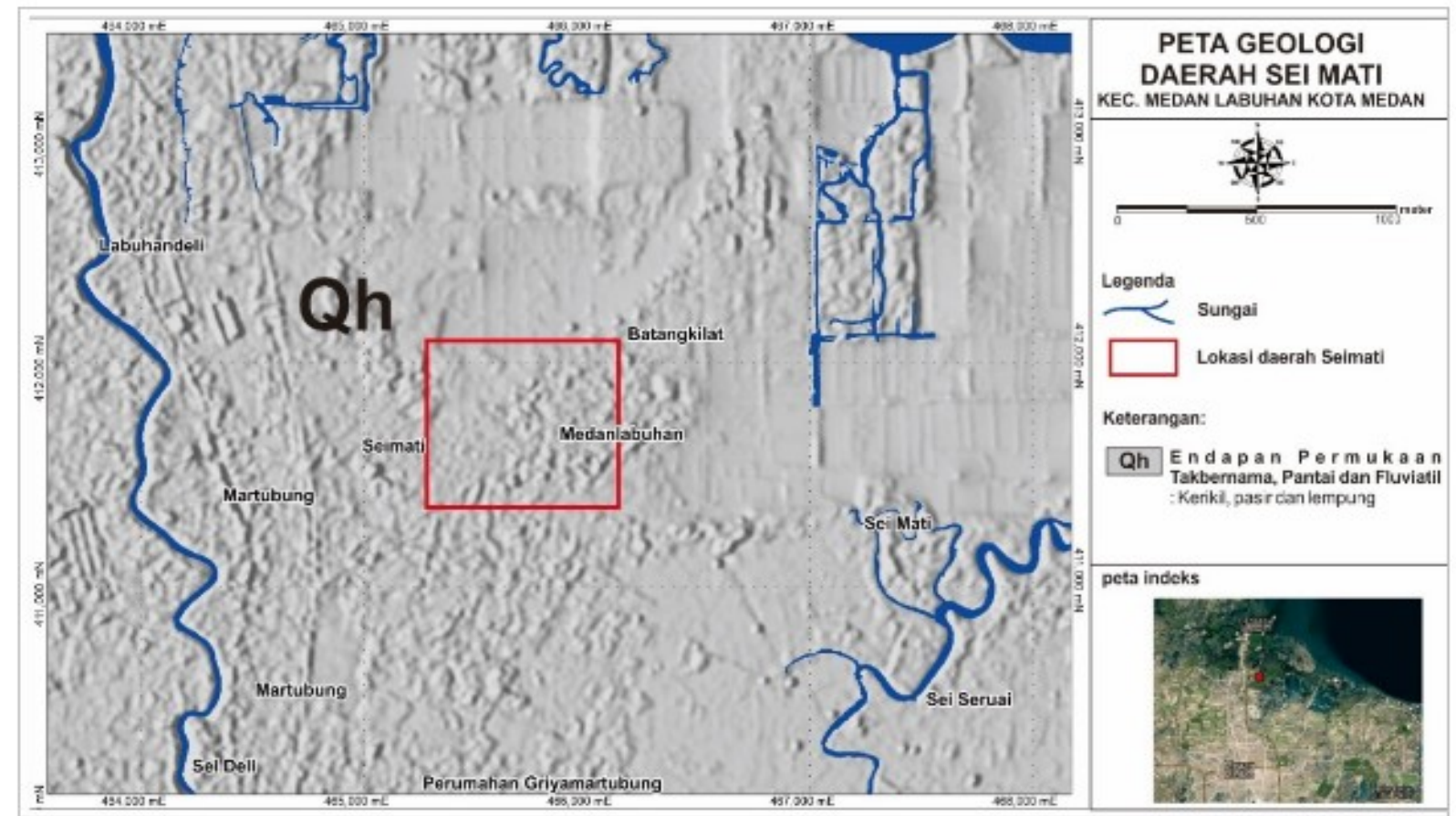

Gambar 2. Peta geologi regional daerah Seimati [3] 


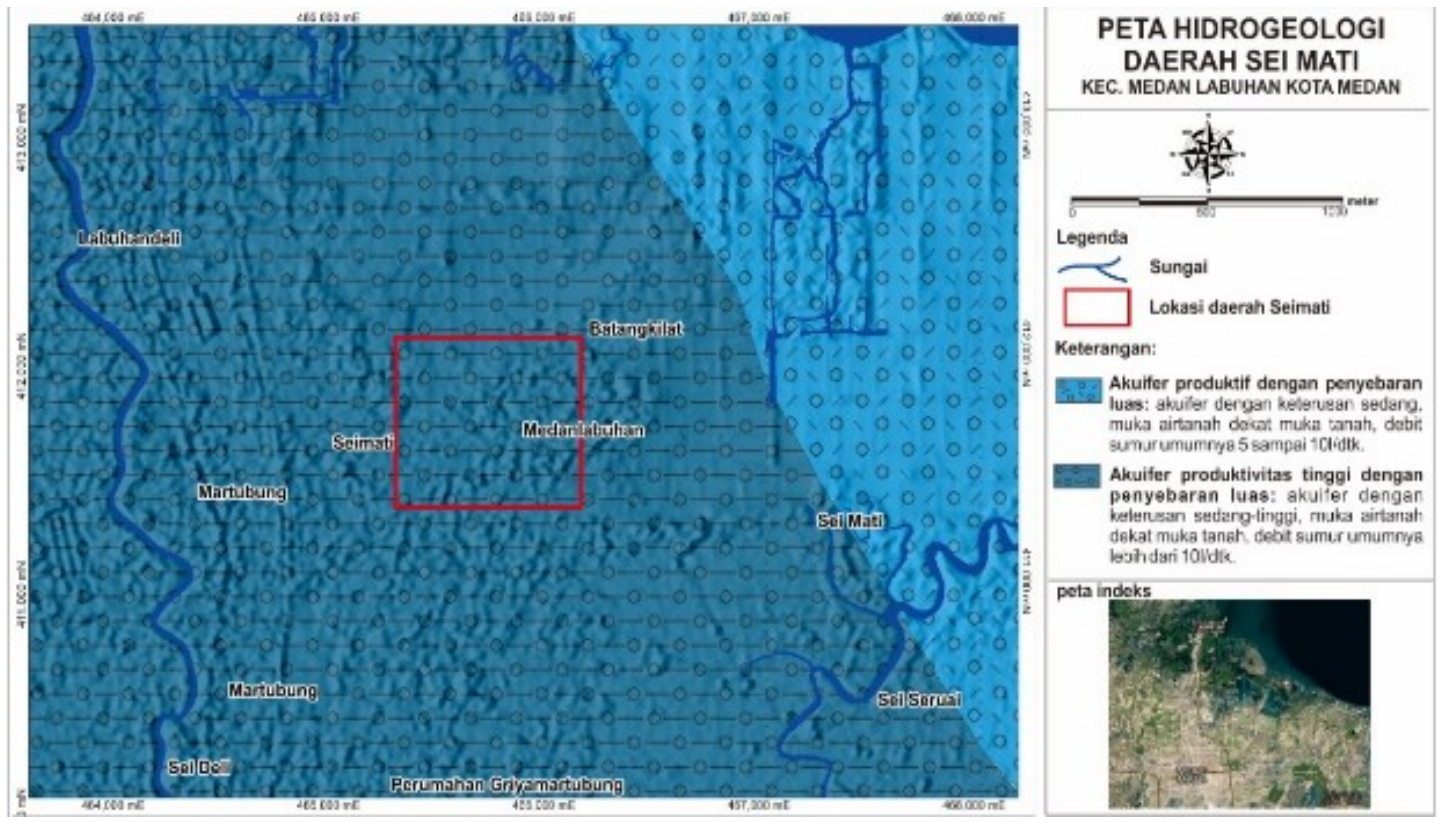

Gambar 3 Peta Hidrogeologi daerah Seimati [2]

\section{METODE UMUM}

Pengukuran geolistrik dimaksudkan untuk mengukur nilai hambatan listrik batuan. Investigasi geofisika yang digunakan dalam penelitian ini adalah metode resistivitas listrik tidak langsung-non-destruktif (permukaan) menggunakan Wenner-Schlumberger [4]. Dalam metode Wenner-Schlumberger, kedalaman lapisan yang diidentifikasi ditentukan oleh jarak elektroda untuk mendapatkan resistivitas berbagai kedalaman. Perkalian nilai resistansi listrik dengan faktor geometri menghasilkan nilai resistivitas semu ( $\rho$ a). Survei resistivitas dilakukan dengan menggunakan metode 2-D, bertujuan untuk melihat distribusi nilai resistivitas secara vertikal dan lateral [5]. Pemetaan geolistrik 2D di daerah sei mati terdapat 2 lintasan yang saling berpotongan dengan arah Utara-Selatan dan Barat-Timur. Hasil pengolahan data akan menghasilkan penampang geolistrik 2-D dengan arah tertentu dengan informasi ketinggian. Hasil ini menunjukkan distribusi aktual dari nilai resistivitas yang akan dikorelasikan dengan geologi dan interpretasi yang diperoleh untuk menggambarkan kondisi bawah permukaan area penelitian [6].

Data yang dihasilkan dari pengukuran di lapangan adalah nilai resistivitas semu untuk semua datum point pada lintasan pengukuran. Nilai resistivitas semu ini merupakan nilai resistivitas dengan faktor koreksi $\mathrm{k}$ sesuai dengan konfigurasi elektroda yang diterapkan [7].

Untuk mendapatkan nilai resistivitas sebenarnya yang menggambarkan variasi sebaran bawah permukaan, maka setiap datum point dibuat dalam stackingchart, dimodelkan sebagai blok resistivitas hasil inversi. Penampang resistivitas dibuat sesuai dengan model blok yang telah terbentuk, sehingga didapatkan gambaran sebaran nilai resistivitas bawah permukaan secara rinci. Pemodelan penampang resistivitas secara digital dilakukan dengan bantuan piranti lunak. Pengolahan data dilakukan untuk kedua tipe konfigurasi pengukuran, yaitu WennerSchlumberger.

Pada survey daerahsei mati resistivity meter yang digunakan adalah Ares 48 Channel, Spasi antar elektroda yang digunakan 10 meter dengan pola lintasan pada gambar 4.

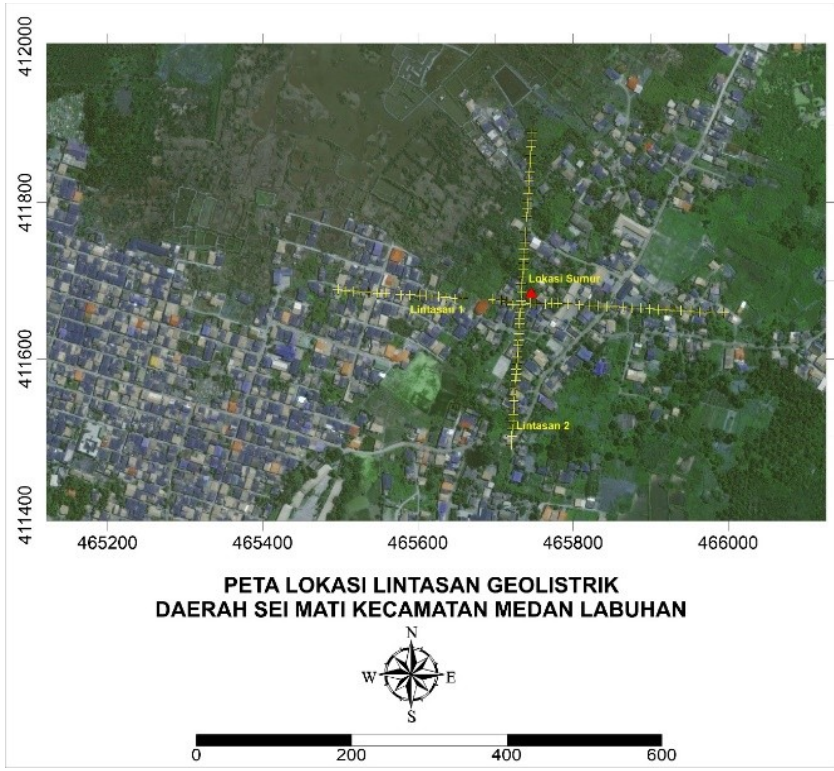

Gambar 4. Peta lintasan geolistrik

Dari hasil pengolahan data geolistrik 2-D yang dilakukan, hasil yang diterima adalah berupa penampang resistivitas yang akan dikorelasikan dengan kondisi dari geologi berupa litologi pada kawasan Sei mati, Kota Medan dan penampang konduktivitas yang akan dikaitkan dengan keberadaan fluida pada daerah ini. Tahapan interpretasi dilakukan dengan menganalisis semua data lintasan terlebih dahulu kemudian dibuat rentang nilai resistivitas yang dikorelasikan dengan kondisi geologi pada kawasan daerah ini. 


\section{HASIL DAN PEMBAHASAN}

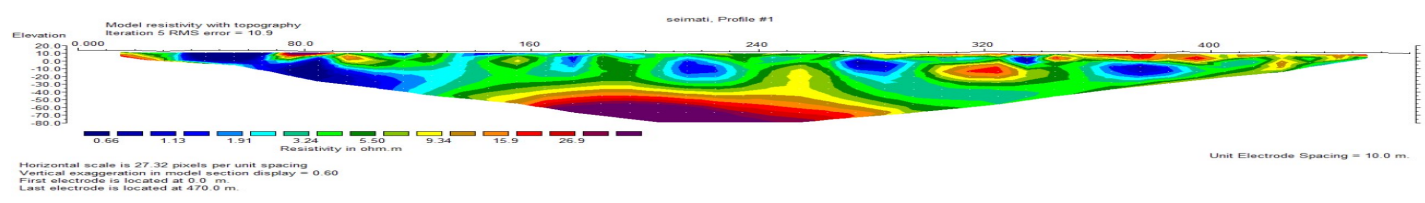

Gambar 5. Penampang resistivitas lintasan 1

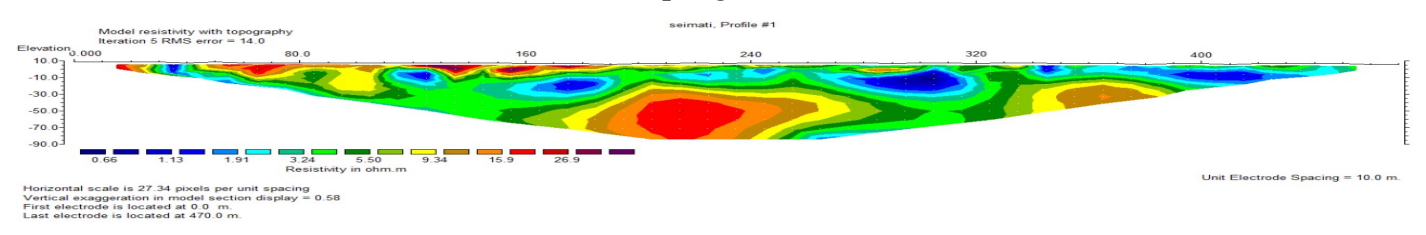

Gambar 6. Penampang resistivitas lintasan 2

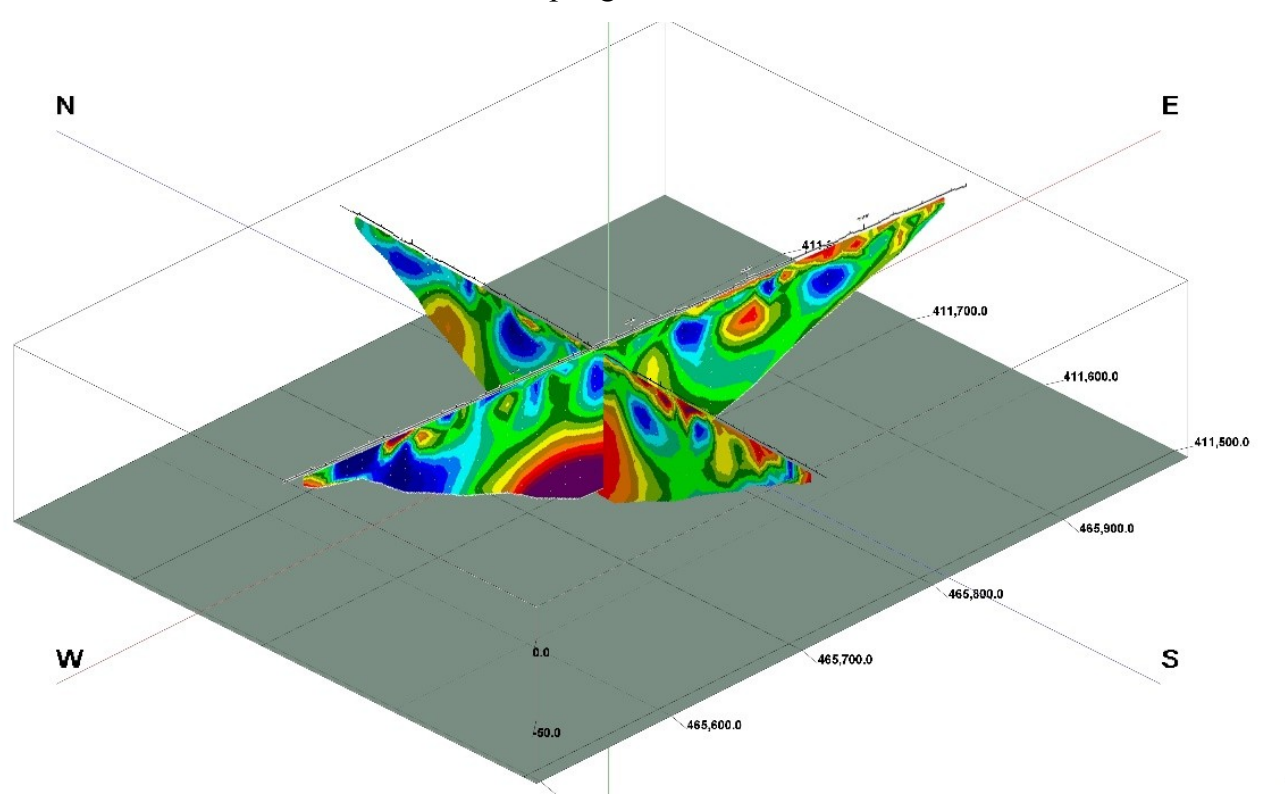

Gambar 7. Diagram pagar antar 2 lintasan

Gambar 6 menunjukkan penampang resistivitas batuan pada lintasan 2 yang berarah Selatan-Utara. Pada lintasan 2 menunjukan sebaran resistivitas yang kompleks dimana ada nilai resistivittas yang sangat rendah (nilai berwarna biru; rho $<10$ ohm.meter), dan ada juga yang tinggi (nilai berwarna ungu; rho $>26.9$ ohm.meter). pada kedalaman 0 40 meter didominasi nilai resistivitas yang rendah ( rho $<10$ ohm.meter). dimana persebaran nilai resistivitas yang sangat rendah membentuk channel-channel (berwarna biru), apabila dikaitkan dengan kondisi geologi, perbearan resistivitas merupakan ciri khas dari endapan fluvial. Kemudian, pada kedalaman 40 hingga 100 meter didominasi oleh nilai resistivitas menegah-tinggi (warma merah-ungu).
Dari korelasi antara geolistrik dan geologi pada kawasan ini, dapat ditarik korelasi untuk penentuan nilai rentang resistivitas untuk tiap satuan geologi yaitu:

Tabel 1. Interpretasi geolistrik 2-D

\begin{tabular}{cccc}
\hline No & $\begin{array}{c}\text { Rentang } \\
\text { Tahanan } \\
\text { Jenis }(\Omega \mathrm{m})\end{array}$ & $\begin{array}{c}\text { Kalsifikasi } \\
\text { Tahanan Jenis }\end{array}$ & $\begin{array}{c}\text { Litologi } \\
\text { Interpretasi }\end{array}$ \\
\hline 1 & $0-4$ & $\begin{array}{c}\text { Tahanan Jenis } \\
\text { rendah } \\
\text { Tahanan Jenis } \\
\text { menengah } \\
\text { Tahanan Jenis } \\
\text { menengah } \\
\text { Tahanan Jenis } \\
\text { Tinggi }\end{array}$ & lempung \\
4 & $10-15$ & Pasir lempungan \\
\hline
\end{tabular}




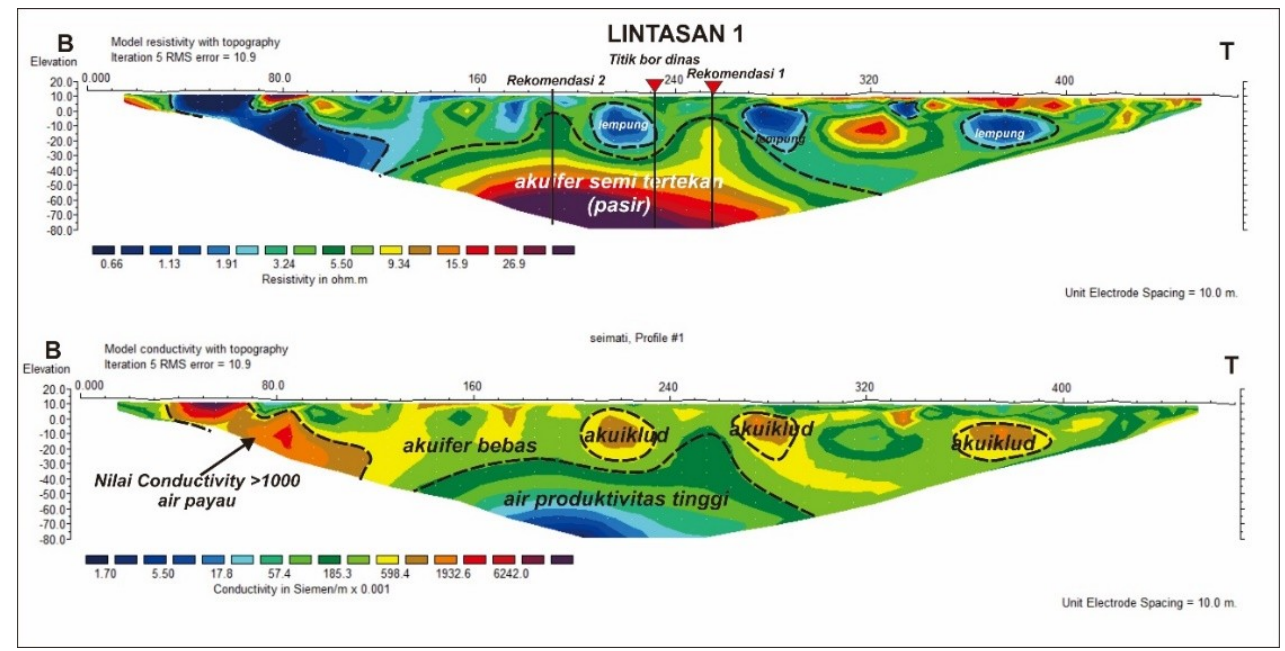

Gambar 8. Penampang 1 interpretasi geolistrik

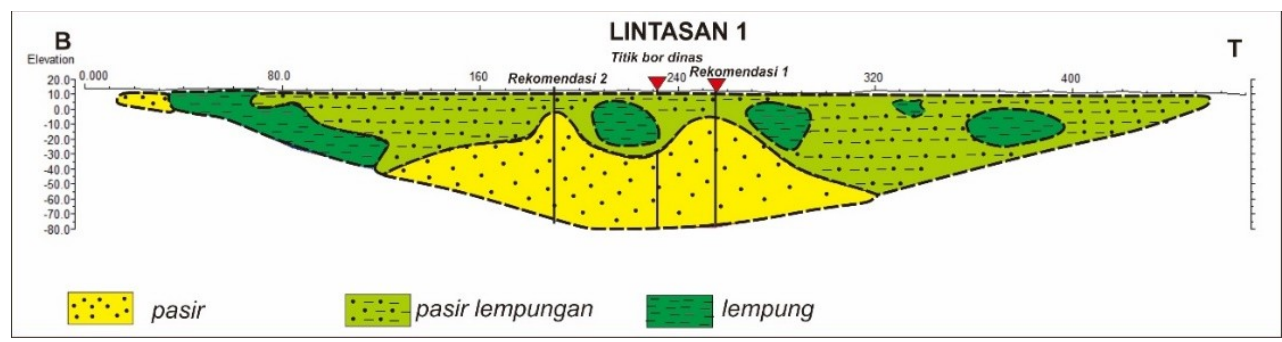

Gambar 9. Penampang 1 interpretasi litologi

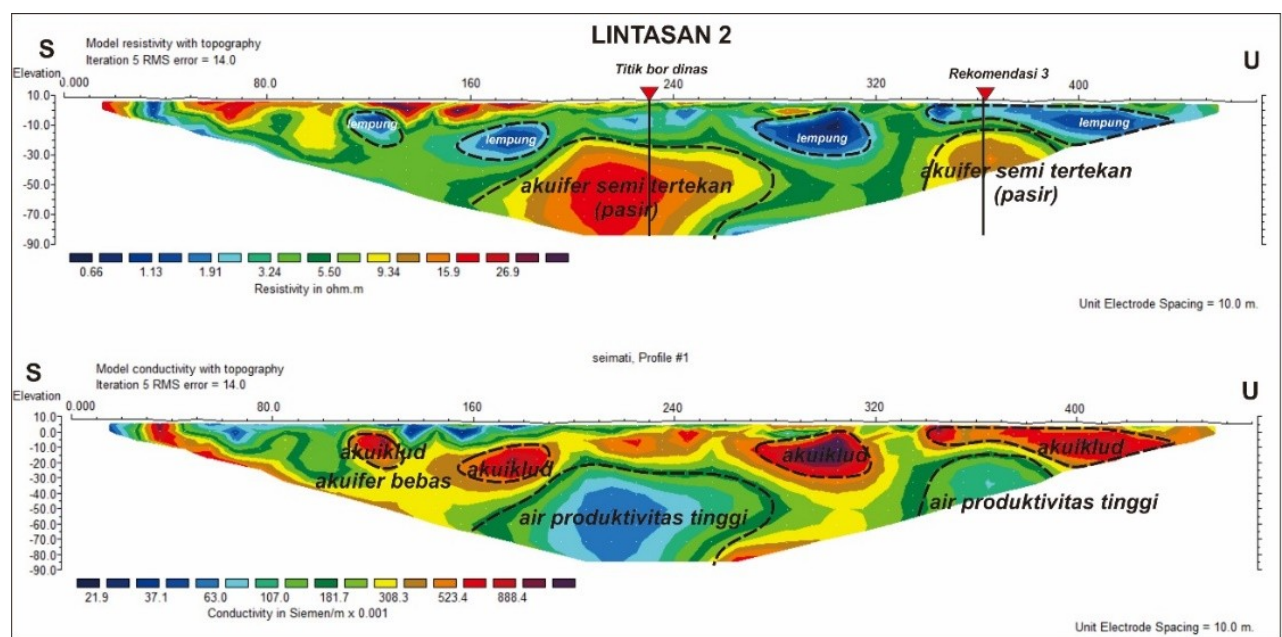

Gambar 10. Penampang 2 interpretasi geolistrik

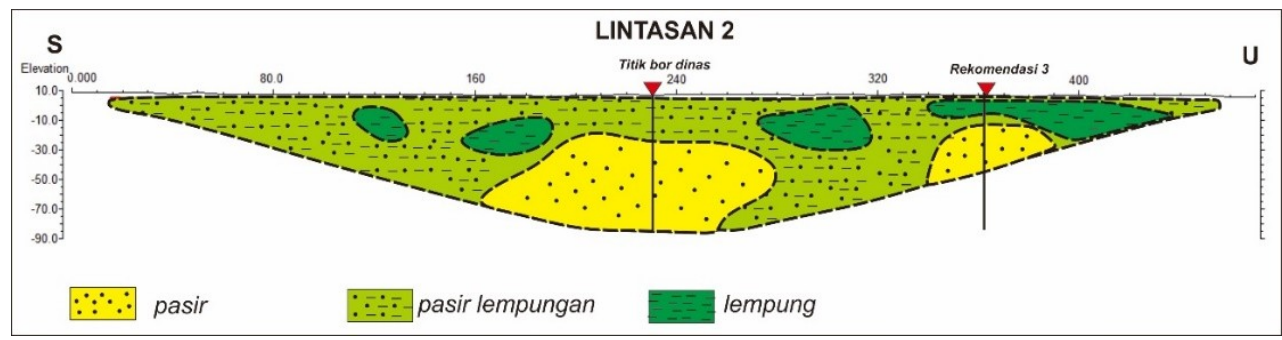

Gambar 11 Penampang 2 interpretasi litologi

Berdasarkan penampang interpretasi geologi, geolistrik dan hidrogeologi diatas menunjukan bahwa:

1. Lapisan pertama (akifer dangkal); berada pada kedalaman berkisar antara $0-50$ meter di bawah permukaan tanah setempat, membentuk pola channelchannel yang menunjukan endapan fluvial dengan nilai tahanan jenis antara $5 \Omega \mathrm{m}-10 \Omega \mathrm{m}$, dengan litologi pasir lempungan, namun dibeberapa tempat dijumpai channel 
lempung yang bersifat akuiklud (tidak dapat menyimpan air).

2. Lapisan kedua (akifer dalam); mulai muncul pada kedalaman 50 meter hingga 100 meter di bawah permukaan tanah setempat, lapisan ini menerus baik utara-selatan atau barat timur.

\section{KESIMPULAN}

1. Terdapat 4 kelompok nilai tahanan jenis yaitu kelompok nilai rendah (0-4 $\Omega \mathrm{m})$, sedang 1 (4-10 $\Omega \mathrm{m})$, sedang 2 (10$15 \Omega \mathrm{m})$ dan tinggi $(>15 \Omega \mathrm{m})$.

2. Kemungkinan Lapisan batuan yang dapat mengandung air ( air tanah dalam) pada nilai tahanan jenis sedang 2 dan tinggi dengan nilai tahanan jenis $>10 \Omega \mathrm{m}$.

3. Lapisan akifer dangkal berada pada kedalaman berkisar antara 0 - 50 meter di bawah permukaan tanah setempat, membentuk pola channel-channel yang menunjukan endapan fluvial dengan nilai tahanan jenis antara $5 \Omega \mathrm{m}-10$ $\Omega \mathrm{m}$, dengan litologi pasir lempungan, namun dibeberapa tempat dijumpai channel lempung yang bersifat akuiklud (tidak dapat menyimpan air).

4. Lapisan akifer dalam; mulai muncul pada kedalaman 50 meter hingga 100 meter di bawah permukaan tanah setempat, lapisan ini menerus baik utara-selatan atau barat timur.

\section{UCAPAN TERIMA KASIH}

Terima kasih kami ucapkan kepada Laboratorium Geofisika Fakultas Teknik Geologi Unpad yang memberikan dukungan kepada tim peneliti sehingga paper ini dapat tersusun dengan baik.

\section{DAFTAR PUSTAKA}

[1] Selles, A. (2014). Multi-disciplinary study on the hydrogeological behaviour of the Eastern flank of the Merapi Volcano, Central Java, Indonesia (Doctoral dissertation, Paris 6).

[2] Sjaiful Ruchijat dan A. Sukrisna (2008). Peta Cekungan Air Tanah Pulau Sumatera Lembar V, Skala 1: 250.000 .

[3] Cameron, N.R., Aspden, J.A., Bridge, D,McC., Djunuddin, A., Ghazali, S.A., Harahap, H., Hariwidjaja, S., Johari, Kartawa, W., Keats, W., Ngabito, H., Rock, N.M.S dan Whandoyo, H., 1982. Peta Geologi Lembar Medan, Sumatra, Skala 1 : 250.000, Puslitbang Geologi, Bandung.

[4] Reynolds, J.M. (1997). An Introduction to Applied and Environmental Geophysics. Wiley, New York, pp: 796.

[5] Telford, William Murray, W. M. Telford, L. P. Geldart, Robert E. Sheriff, and R. E. Sheriff. Applied geophysics. Cambridge university press, 1990.

[6] Fetter, C. W. (2018). Applied hydrogeology. Waveland Press.

[7] Alfadli, M. K., \& Natasia, N. (2017). Geoelectricity Data Analysis For Identification The Aquifer Configuration In Bandorasawetan, Cilimus, Kuningan, West Java Province. Journal of Geoscience, Engineering, Environment, and Technology, 2(4), 278284. 